\title{
Comparative evaluation of osseointegration of dental implants in patients with type 2 diabetes and diffuse toxic goiter
}

\author{
Khassanov Sardor Mukhitdinovich \\ master student Tashkent State Dental Institute.
}

\section{Email address:}

sardor.khasanov2016@yandex.ru (Khassanov Sardor Mukhitdinovich).

\section{Kudratov Shuxrat Sheraliyevich}

Master of Medical sciences Tashkent State Dental Institute.

Aliyeva Dinara Abralovna

Master of Medical sciences Regional Endocrinology Dispensary.

\section{Oralov Anvar Xolmanovich}

doctor Regional Endocrinology Dispensary.

\section{To cite this article:}

Khassanov Sardor, Kudratov Shuxrat, Aliyeva Dinara, Oralov Anvar. Comparative evaluation of osseointegration of dental implants in patients with type 2 diabetes and diffuse toxic goiter. Journal of research in health science. Vol. 1, No. 2, 2018, pp. 85-91. DOI 10.26739/2523-1243

$$
\text { dol http://dx.doi.org/10.26739/2523-1243/-2018-1-2-14 }
$$

\footnotetext{
Abstract: According to the results of analyzes of the studies, osteopenic syndrome and disturbance of microcirculation in vessels in patients with type 2 diabetes and diffuse thyrotoxic goiter were revealed. Preoperative correction of hormonal imbalance, the use of targeted antibiotics, the use of the "Ostell ISQ" device (Resonance Frequency Analysis) to assess the coefficient of primary stability of the implant and distant osseointegration, allows us to prevent complications associated with unreasonable early loading of the implant and the selection of the optimal term for prosthetics, terms of orthopedic treatment.
}

Keywords: Dental implantation, diffuse thyrotoxic goiter, diabet 2 type, ossteointegration, osteoporosis.

The leading role in the formation of osteopenic syndrome in diabetes mellitus (DM) and diffuse thyrotoxic goiter (DTG) is played by violations of $\mathrm{Ca}$ homeostasis. The skeleton, like any organ and tissue, is in a state of constant self- renewal, remodeling, which is the result of two processes: resorption and formation (modeling). Resorption increases when the level of $\mathrm{Ca}$ in the blood tends to decrease. Released from demineralized bone sites, $\mathrm{Ca}$ enters the blood, restoring its 
Khassanov Sardor, Kudratov Shuxrat, Aliyeva Dinara, Oralov Anvar. Comparative evaluation of osseointegration of dental implants in patients with type 2 diabetes and diffuse toxic goiter

temporary deficit. Thus, the skeleton performs the depot's function of this element. [1]

The exchange of $\mathrm{Ca}$ in the body is under the strict regulatory control of a complex, multilevel hormonal system: parathyroid hormone $(\mathrm{PTH})$; active hormonal form of vitamin D - calcitriol; calcitonin, growth hormone, sex hormones, insulin, etc.

In recent decades, the prevalence of diabetes mellitus (DM) has become an epidemic: if at the end of last century the number of people with diabetes in the world did not exceed 130 million, now they amount to more than 300 million, and by 2030, according to forecasts International diabetic association, will increase by 1.5 times and will amount to 438 million people, mainly due to patients with type 2 diabetes, which account for more than $90 \%$ of the total number of patients. To date, there is a trend not only to increase the incidence of type 2 diabetes, but also the development of this pathology at a younger age, which is associated with urbanization of the territory, an increase in the prevalence of obesity and sedentary lifestyle.

Diffuse toxic goiter affects about $1 \%$ of the population, its prevalence is higher in iodine-deficient areas. Women suffer 10 times more often, the greatest risk of DTG development is in young and middle age, in 20-40 years, which is typical for autoimmune pathology.

For Uzbekistan, the medical and social significance of diffusely toxic goiter is due to the fact that, due to biogeochemical characteristics, most of the inhabited territory of the republic is characterized by iodine deficiency in the external environment. In 2010, the staff of the SRIE (Scientific Research Institute of
Endocrinology) conducted an epidemiological survey of the territory of Uzbekistan; On average, the frequency of endemic goiter in the republic was $70 \%$.

Many serious diseases are complicated by diabetes, which makes the patient worse and complicates treatment. Very often, diabetes is accompanied by diseases of the thyroid gland. People with diabetes, as a rule, are at risk of developing thyroid diseases. About $6 \%$ of the general population with impaired thyroid function [2]. The prevalence of thyroid diseases is increased to $10 \%$ in people with diabetes. One of the actual problems in thyedology is the choice of a method for treating patients with nodular goiter in the older age group in the presence of diabetes mellitus. [2]

When discussing the mechanisms of the development of diabetic osteo pathology, a certain role is assigned, vascular and neurological complications, genetic preconditions for osteogenesis insufficiency in diabetes mellitus, and hormonal imbalance, in particular, insulin deficiency and violation of secretion of calcium regulating hormones. According to many authors, in patients with type 2 diabetes after removal of the teeth, as well as other surgical interventions, the terms are prolonged and the regeneration processes worsen [3]

For normal growth and development of the skeleton, as well as to maintain bone metabolism, interaction of various factors is necessary. The main role in this case belongs to calcium-regulating hormones (parathyroid hormone, calcitonin and 1,25-dihydroxyvitamin D), which, acting in conjunction with locally produced factors (cytokines, growth factors), regulates bone cell activity and calcium metabolism. 
An important place in the regulation of bone metabolism is the thyroid gland (thyroid gland) and thyroid hormones produced by it. With excess thyroid function there are changes in the bone system, leading to a decrease in bone mineral density and development of OP.

DTG leads to a disturbance of bone balance and the predominance of bone resorption over bone formation. Under the influence of an increased level of TG, the process of bone reshaping is accelerated. This leads to a negative calcium balance and a decrease in bone mass. In patients with DTG, osteoporosis is detected in various parts of the skeleton

The aim of the study is to study the osseointegration of dental implants in patients with type 2 diabetes and diffuse thyrotoxic goiter

\section{Materials and methods of research}

The examined patients were recruited from the Tashkent State Institute of Dentistry who applied for medical assistance to the outpatient clinic and the Endocrinology Research Institute of the Ministry of Health of the Republic of
Uzbekistan, as well as in the regional endocrinology dispensary in Karshi, Kashkadarya region. The work was performed at the Department of Surgical Dentistry and Dental Implantology.

A comparative method studies the process of osseointegration of dental implants in patients with DTG and type 2 diabetes

Patients are divided into 4 groups of 20 people for further dental implantation:

o The first group of patients without a history of diabetes and DTG

o The second group of patients with a history of type 2 diabetes

o The third group of patients having a history of DTG

o The fourth group of patients having a history of DTG and DM of type 2

Patients underwent local treatment of manifestations of DTG and type 2 diabetes in the oral cavity (Fig. 1) and together with endocrinologists of the Endocrinology Research Institute and the Regional Endocrinology Dispensary in Karshi, general treatment of these diseases was carried out.
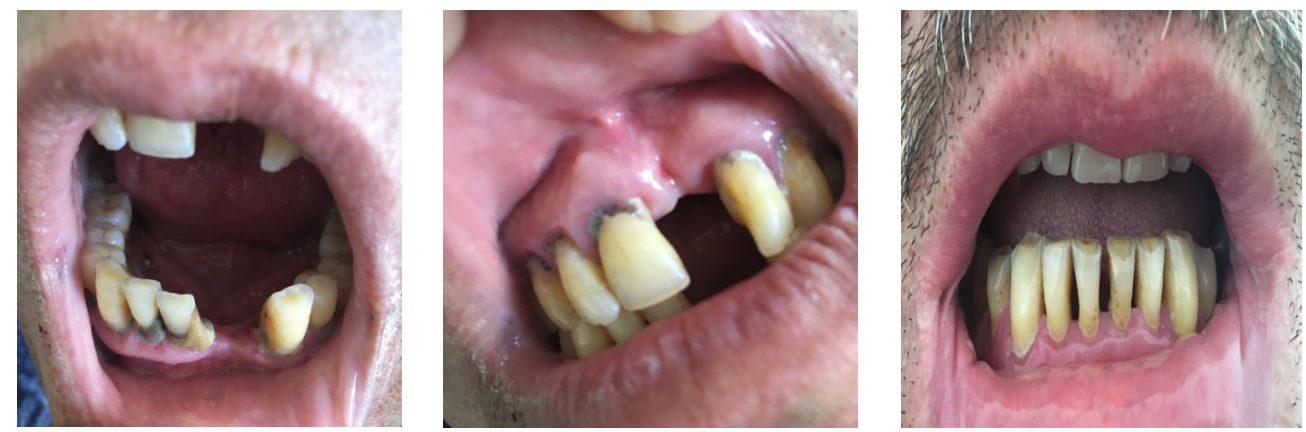

Patients with unsatisfactory hygienic condition of the oral cavity were assigned professional cleaning of the oral cavity, rinsing with the drug "Loroben".

To prepare patients for the operation of dental implantation, doctors of the Endocrinology Research Institute and the regional endocrinological dispensary of the city of Karshi were prescribed preparations of Beta insulin $\mathrm{N}$ and Gensulin 3 times a day for 1 tablet. Patients with diffuse thyrotoxic goiter were assigned Merkazolil $6 \mathrm{mg} 2$ tablets 3 times a day for 3-4 months, then at a rate of 
Khassanov Sardor, Kudratov Shuxrat, Aliyeva Dinara, Oralov Anvar. Comparative evaluation of osseointegration of dental implants in patients with type 2 diabetes and diffuse toxic goiter

hormone levels, the dose was dropped every month for 1 tablet

A laboratory and biochemical blood test was performed. Of great importance is the diagnosis of the structural state of bone tissue for primary stabilization and distant osteoinpression of the dental implant. For these purposes, we chose the method of computer beam tomography, since it is one of the best methods for the correct determination of the ointegration of the implant. Computer tomography (CT) is one of the modern methods of radiation diagnosis, which is based on the use of $\mathrm{X}$-rays. In contrast to the traditional $\mathrm{X}$ ray study, the result of computed tomography is a digital (digital) image of the cross section of the object under study. According to $\mathrm{CT}$, the position of the dental implant was compared with the anatomical formations (maxillary sinus, mandibular canal, mental opening), its shape, and relative density of bone tissue. According to the results of computed tomography, bone density was assessed according to the Haunsfield scale.

To prevent purulent inflammatory complications of the microflora of the oral cavity, fluid was taken from patients with diabetes mellitus and hyperthyroidism into a tube with a preliminary rinsing of $5 \mathrm{ml}$ with physiological saline, then saliva was delivered to the laboratory of the Tashkent Dental Institute for 2 hours. At the Department of Microbiology, then for further study, microflora was sown on differential diagnostic nutrient media.

With type 2 diabetes and DTG there is a disturbance of blood circulation in small vessels, which is reflected in the quality of healing of the postoperative deffect. To study blood circulation in small vessels and capillaries, a method was used to examine the fundus of OCT Spectralis by HEILDERBERG ENGINEERING in Germany. The study was conducted in the ophthalmological clinic Saif Optima in Tashkent.

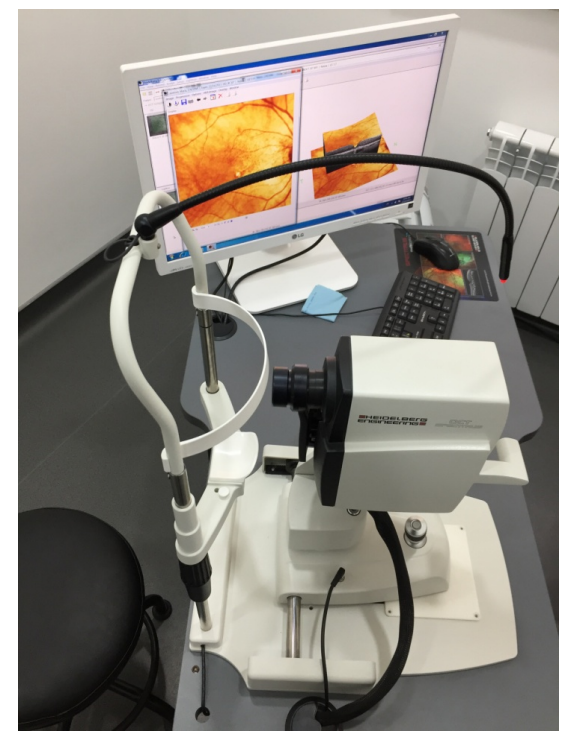

All patients were assessed by osteoplastic osteointegration of the dental implants with a frequency resonance device Osstell ISQ MEGAGEN (Implant Stability Quotient), which was performed during the operation on an open wound, after the operation, at $1,2,4,6,9,12$ and 24 months, these periods in groups 1-3 often coincided during the period of prosthesis and functioning of the prosthesis. The measurement of ISQ / CSI during the operation played a decisive role in assessing the primary stability on which the preliminary tionary period of the second phase of surgery - the installation of the superstructure or the beginning of functional loading of the implant using a prosthesis

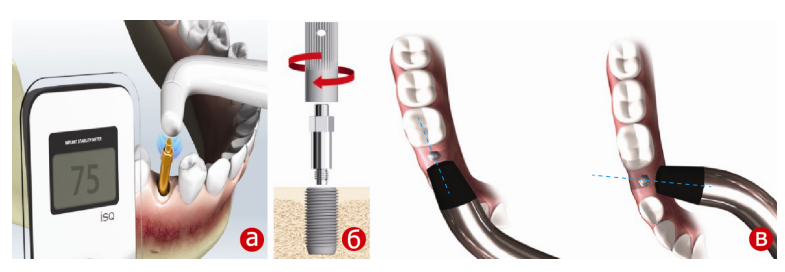




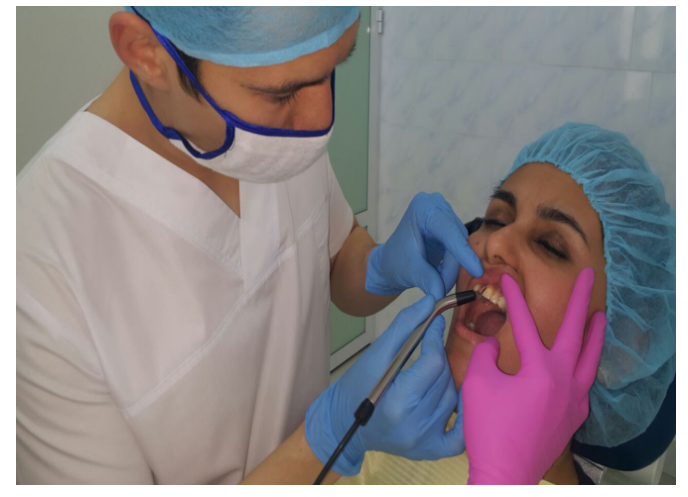

\section{Results of the study}

The criteria for the cone ray computed tomography were: evaluation of the position of the dental implant relative to the anatomical formations (maxillary sinus, mandibular canal, chin aperture), the structure and relative density of the bone surrounding the dental implant. The presence of the enlightenment zone was

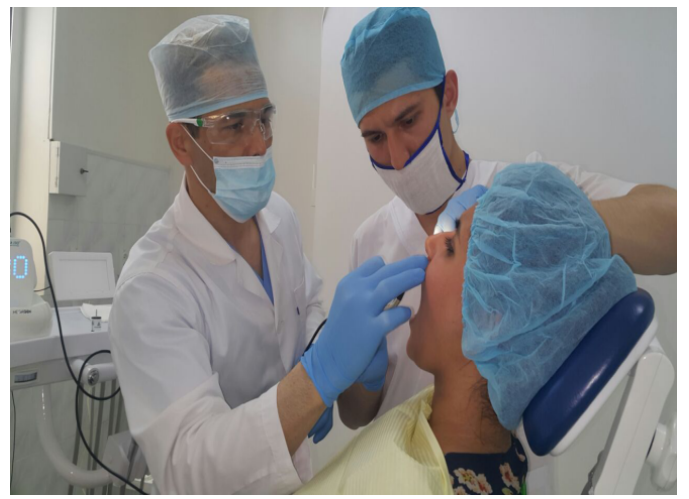

regarded as an unfavorable result of the osseointegration of the dental implant. The structure of the shadow of bone tissue was assessed as non-uniform, areas of dense bone tissue alternated with areas of bone enlightenment - which is the optimal result. Density of tissues was estimated by Hounsfield in figures (HU CT number, "Hounsfield Unit"),

Taking into account the results of the study of blood circulation, the correct tactics of administering the patients was selected:

\begin{tabular}{|l|l|l|}
\hline Diagnosis & $\begin{array}{l}\text { Patients with } \\
\text { type 2 diabetes } \\
\text { mellitus } \\
\text { (number) }\end{array}$ & $\begin{array}{l}\text { Patients with diffuse } \\
\text { toxic goiter (count) }\end{array}$ \\
\hline $\begin{array}{l}\text { Non-pluritransitive } \\
\text { Retinopathy (Diabetic retinopathy 1) }\end{array}$ & 5 & 0 \\
\hline Pre-proliferative retinopathy (diabetic retinopathy 2) & 1 & 0 \\
\hline Proliferative retinopathy (diabetic retinopathy 3) & 2 & 0 \\
\hline Dilation of blood vessels & 5 & 16 \\
\hline
\end{tabular}

The results of a study of the microbiology of saliva helped us choose an antimicrobial drug directed at the action against a particular type of bacteria that prevailed in the saliva of the patient 
Khassanov Sardor, Kudratov Shuxrat, Aliyeva Dinara, Oralov Anvar. Comparative evaluation of osseointegration of dental implants in patients with type 2 diabetes and diffuse toxic goiter

Results of microbiological examination of saliva:

\begin{tabular}{|c|c|c|c|c|c|c|c|c|c|c|}
\hline \multirow{4}{*}{$\begin{array}{l}\text { Group } \\
\text { Microbes }\end{array}$} & \multicolumn{5}{|c|}{ In patients with diabetes mellitus } & \multicolumn{5}{|c|}{ In patients with diffusively toxic goiter } \\
\hline & \multicolumn{5}{|c|}{ The number of microbes in $1 \mathrm{ml}$ of saliva } & \multicolumn{5}{|c|}{ The number of microbes in $1 \mathrm{ml}$ of saliva } \\
\hline & \multirow{2}{*}{$\begin{array}{l}\text { Before } \\
\text { operation }\end{array}$} & \multicolumn{4}{|c|}{ After dental implantation } & \multirow{2}{*}{$\begin{array}{l}\text { Before } \\
\text { operation }\end{array}$} & \multicolumn{4}{|c|}{ After dental implantation } \\
\hline & & $3^{\text {rd }}$ day & $\begin{array}{l}1^{\text {st }} \\
\text { week }\end{array}$ & $\begin{array}{l}2^{\text {nd }} \\
\text { week }\end{array}$ & $\begin{array}{l}1^{\text {st }} \\
\text { month }\end{array}$ & & $3^{\text {rd }}$ day & $\begin{array}{l}1^{\text {st }} \\
\text { week }\end{array}$ & $\begin{array}{l}2^{\text {nd }} \\
\text { week }\end{array}$ & $\begin{array}{l}1^{\text {st }} \\
\text { month }\end{array}$ \\
\hline $\begin{array}{c}\text { Total } \\
\text { Anaerobes }\end{array}$ & $5,15+-0,16$ & $\begin{array}{l}4.30+- \\
0,15\end{array}$ & $\begin{array}{l}6,15+- \\
0,18\end{array}$ & $\begin{array}{l}6,0+- \\
0,15\end{array}$ & $\begin{array}{l}6,10+- \\
0,21\end{array}$ & $5,30+-0,14$ & $\begin{array}{l}4,90+- \\
0,20\end{array}$ & $\begin{array}{l}5,55+- \\
0,23\end{array}$ & $\begin{array}{l}5,80+- \\
0,31\end{array}$ & $\begin{array}{l}6,01+- \\
0,5\end{array}$ \\
\hline Lactobacilli & $3,30+-0,17$ & $\begin{array}{l}3,0+- \\
0,14\end{array}$ & $\begin{array}{l}5,11+- \\
0,15\end{array}$ & $\begin{array}{l}5,0+- \\
0,17\end{array}$ & $\begin{array}{l}4,60+- \\
0,16\end{array}$ & $4,0+-0,15$ & $\begin{array}{l}3,8+- \\
0,21\end{array}$ & $\begin{array}{l}4,7+- \\
0,19\end{array}$ & $\begin{array}{l}4,6+- \\
0,24\end{array}$ & $\begin{array}{l}5,1+- \\
0,3\end{array}$ \\
\hline Peptostreptococcus & $2,85+-0,11$ & 0 & $\begin{array}{l}2,10+- \\
0,2\end{array}$ & 0 & $\begin{array}{l}1,0+- \\
0,01\end{array}$ & $2,64+-0,13$ & $\begin{array}{l}1,56+- \\
0,17\end{array}$ & $\begin{array}{l}1,1+- \\
0,33\end{array}$ & $\begin{array}{l}0,9+- \\
0,5\end{array}$ & $\begin{array}{l}1,94+- \\
0,15\end{array}$ \\
\hline Total number of aerobes & $5,60+-0,18$ & $\begin{array}{l}6,10+- \\
0,18\end{array}$ & $\begin{array}{l}5,30+- \\
0,19\end{array}$ & $\begin{array}{l}7,10+- \\
0,21\end{array}$ & $\begin{array}{l}6,30+- \\
0,23\end{array}$ & $4,91+-0,20$ & $\begin{array}{l}5,56+- \\
0,31\end{array}$ & $\begin{array}{l}5,1+- \\
0,26\end{array}$ & $\begin{array}{l}4,7+- \\
0,55\end{array}$ & $\begin{array}{l}3,3+- \\
0,64\end{array}$ \\
\hline Staph. Aureus & 0 & $\begin{array}{l}2,10+- \\
0,11\end{array}$ & 0 & $\begin{array}{l}2,10+- \\
0,1\end{array}$ & 0 & $1,1+-0,13$ & $\begin{array}{l}1,3+- \\
0,21\end{array}$ & $\begin{array}{l}0,9+- \\
0,16\end{array}$ & $\begin{array}{l}1,8+- \\
0,6\end{array}$ & 0 \\
\hline Staph. epidermidis & $2,0+-0,10$ & $\begin{array}{l}3,0+- \\
0,13\end{array}$ & $\begin{array}{l}1,30+- \\
0,01\end{array}$ & $\begin{array}{l}3,0+- \\
0,13\end{array}$ & $\begin{array}{l}2,60+- \\
0,11\end{array}$ & $1,8+-0,38$ & $\begin{array}{l}2,2+- \\
0,19\end{array}$ & $\begin{array}{l}2,6+- \\
0,27\end{array}$ & $\begin{array}{l}3,0+- \\
0,33\end{array}$ & $\begin{array}{l}2,0+- \\
0,45\end{array}$ \\
\hline Str. salivarius & $3,45-+0,15$ & $\begin{array}{l}4,10+- \\
0,15\end{array}$ & $\begin{array}{l}4,0+- \\
0,21\end{array}$ & $\begin{array}{l}5,0+- \\
0,21\end{array}$ & $\begin{array}{l}4,15+- \\
0,17\end{array}$ & $2,0+-0,45$ & $\begin{array}{l}2,8+- \\
0,41\end{array}$ & $\begin{array}{l}3,1+- \\
0,17\end{array}$ & $\begin{array}{l}3,33+- \\
0,78+\end{array}$ & $\begin{array}{l}2,41+- \\
0,11\end{array}$ \\
\hline Str. mutans & $2,15-+0,12$ & $\begin{array}{l}2,0+- \\
0,11\end{array}$ & $\begin{array}{l}3,0+- \\
0,15\end{array}$ & $\begin{array}{l}5,0+- \\
0,8\end{array}$ & $\begin{array}{l}4,+- \\
0,15\end{array}$ & $1,73+-0,12$ & $\begin{array}{l}1,98+- \\
0,16+\end{array}$ & $\begin{array}{l}1,65+- \\
0,22\end{array}$ & $\begin{array}{l}3,1+- \\
0,39\end{array}$ & $\begin{array}{l}2,7+- \\
0,3\end{array}$ \\
\hline Str. Mitis & $2,85+-0,13$ & $\begin{array}{l}2,10+- \\
0,10\end{array}$ & 0 & 0 & $\begin{array}{l}3,0+- \\
0,12\end{array}$ & $2,63+-0,56$ & $\begin{array}{l}3,1+- \\
0,48\end{array}$ & $\begin{array}{l}2,86+- \\
0,34\end{array}$ & $\begin{array}{l}3,0+- \\
0,19\end{array}$ & $\begin{array}{l}1,89+- \\
0,17\end{array}$ \\
\hline Protea & $1,45+-0,01$ & 0 & 0 & 0 & 0 & $0,8+-0,2$ & $\begin{array}{l}0,78+- \\
0,09\end{array}$ & 0 & 0 & $\begin{array}{l}0,65+- \\
0,23\end{array}$ \\
\hline Escherichia & $1,0+-0,01$ & 0 & 0 & $\begin{array}{l}1,60+- \\
0,1\end{array}$ & 0 & 0 & 0 & $\begin{array}{l}0,65+- \\
0,15 \\
\end{array}$ & 0 & $\begin{array}{l}0,36+- \\
0,26\end{array}$ \\
\hline fungus & $3,0+-0,15$ & $\begin{array}{l}2,30+- \\
0,11\end{array}$ & 0 & 0 & $\begin{array}{l}1,30+- \\
0,1\end{array}$ & $2,1+-0,43$ & $\begin{array}{l}2,6+- \\
0,41\end{array}$ & 0 & $\begin{array}{l}1,9+- \\
0,53\end{array}$ & $\begin{array}{l}1,8+- \\
0,29\end{array}$ \\
\hline
\end{tabular}

The optimal ISQ / CSI index for a safe functional load is above 70 units. When assessing osseointegration, the accuracy of measurements of the stability of implants, the "Osstell" instrument (Sweden), with sufficiently rigid attachment of parts, repeatability was established with high accuracy.

In the 1st group in patients without an anamnesis of endocrine disorders, the ISQ / CSI index during the implantation had an average of $75( \pm 2.0)$, after 1 month the ISQ / CIC remained within $79( \pm 1.5)$ and in the 2-4-6-9-12 months ISQ / CSI indicators with a tendency to increase from $82( \pm 1.5)$ to $86( \pm 1.5)$. After 24 months the ISQ / CSI remains stable unchanged.

In the 2nd group of patients with a history of type 2 diabetes during the implantation, the ISQ / CSI $74( \pm 1.5), 1$ month $75( \pm 1)$ and 2-4-6-9-12 months ISQ / CSI with a tendency to increase from $77( \pm 2)$ to $80( \pm 2)$. After 24 months, the ISQ / CSI increases to $79( \pm 1.5)$.

In the third group of patients with DTG, the ISQ / CSI indicators implantation time $75( \pm 01,0)$, after 1 month $76( \pm 1,5)$ and in terms of 2-4-69-12 months the ISQ / CSI indicators with the tendency to increase to 80 ( \pm $0.5)$. After 24 months, the ISQ / CSI is increased to $81( \pm 1.5)$.

In the 4th group of patients with a history of DTG in the background of DM 2 , the average ISQ / CSI during implantation $68( \pm 1.0)$, after 1 month 71 ( \pm 2.0), and at terms 2-4-6-9-12 month ISQ / CSI indicators with a tendency to increase from $71( \pm 1.0)$ to 78 ( \pm 1.5$)$. After 24 months, the ISQ / CSI is increased to $80( \pm 1.5)$ 


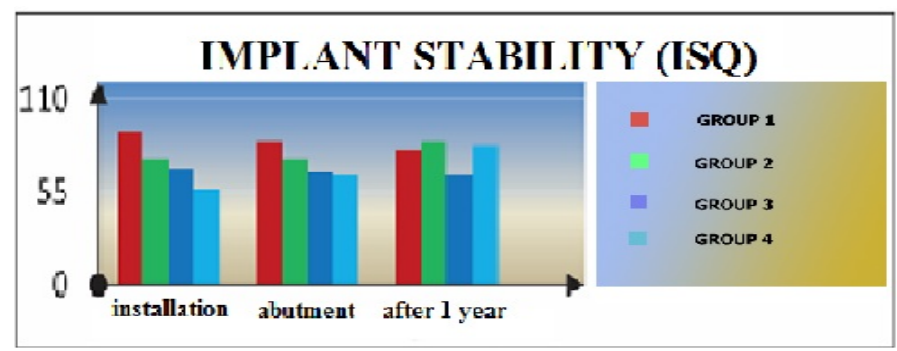

All patients are traditionally equipped with implants with the same shallow screws of the intraosseous part

\section{Bibliography:}

1. Tovmasyan David Rafaelovich thesis for the scientific degree of the candidate of medical sciences "The state of remodeling of the jawbones in dental surgical interventions in patients with type 2 diabetes mellitus and with osteopenic syndrome" Strokov I.A.

2. Sadykova N.G., Tagaeva G.T. Influence of type II diabetes on the course of nodular goitre of the thyroid gland in persons of the older age group // Young Scientist. - 2017. - № 20. - P. 203-205.

3. Ferguson DJ, Wilcko M.T. Accelerating orthodontics by altering alveolar bone density. Good Pract. 2001; 2; 2-4

4. Gun'kov M.V., Features of diagnostics and complex therapy when using the method of dental implantation in patients with systemic osteoporosis: dis. cms - M 2009 C-135 